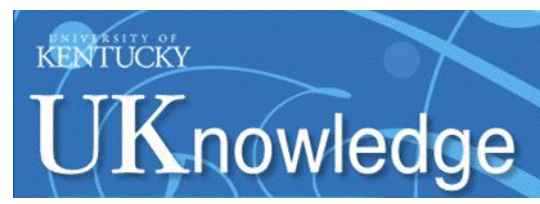

Kentucky Law Journal

1943

\title{
A Rationale of Criminal Negligence
}

Roy Mitchell Moreland

University of Kentucky

Follow this and additional works at: https://uknowledge.uky.edu/klj

Part of the Criminal Law Commons, and the Torts Commons

Right click to open a feedback form in a new tab to let us know how this document benefits you.

\section{Recommended Citation}

Moreland, Roy Mitchell (1943) "A Rationale of Criminal Negligence," Kentucky Law Journal: Vol. 32: Iss. 1, Article 1.

Available at: https://uknowledge.uky.edu/klj/vol32/iss1/1

This Article is brought to you for free and open access by the Law Journals at UKnowledge. It has been accepted for inclusion in Kentucky Law Journal by an authorized editor of UKnowledge. For more information, please contact UKnowledge@lsv.uky.edu. 


\section{KENTUCKY LAW JOURNAL}

Volume XXXII November, 1943 Number 1

\section{A RATIONALE OF CRIMINAL NEGLIGENCE}

By Roy MoReLAND*

PART I

\section{HISTORICAL INTRODUCTION}

\section{SECTION 1. THE BACKGROUND OF CRIMINAL NEGLIGENCE}

Negligence entered the cruminal law as a limitation on the defense of misadventure.

The rules as to what would amount to musadventure were gradually evolved. Far into the twelfth century the king decided, in each case, whether life and limb should be spared. ${ }^{1}$ One who killed another by misadventure or in self defense was still guilty of a crime in the thirteenth century, ${ }^{2}$ although he

* A.B., Transylvania College, 1920; LL.B., University of Kentucky College of Law, 1923; J.D., University of Chicago Law School, 1928; S.J.D., Harvard University, 1942. Professor of Law, University of Kentucky College of Law; contributor to various legal periodicals.

12 Pollock and Maitland, History of English Law (1911) 483.

- Cases in the King's Court: "(1214). Roger of Stanton was arrested because in throwing a stone he by misadventure killed a gurl. And it is testified that this was not by felony. And this was shown to the king, and the kang moved by pity pardoned him the death. So let hum be set free." 1 Seldon Society, Select Pleas of the Crown (1887) No. 114. "(1225). Mabel, Derwin's daughter, was 
deserved a pardon. Nevertheless, a pardon was necessary ${ }^{3}$ and the Statute of Gloucester (1278) regulated the procedure to be followed in such cases. Since the defense depended upon royal favor, determined rules were, as yet, impossible.

However, certain princuples were emerging. Bracton made a division of the cases based upon the lawfulness or unlawfulness of the act. In the latter case the killer was liable. In the former, blame was not "imputable to hum" unless he had failed to use "due diligence." 4

Thus was an over-statement of existing English law. Negligence was as yet non-exustent and Bracton's idea of "due care" was taken over from the canonists. ${ }^{5}$ But his statement

playing with a stone at Yeovil, and the stone fell on the head of Walter Critele, but he had no harm from the blow, and a month after this he died of an infirmity, and she fled to church for fear, but (the jurors) say positively that he did not die of the blow. Therefore let her be in custody until the king be consuited." Id. No. 188 . Perkms, A re-examination of Malice Aforethought (1934) 43 Yale L. J. 537, 539-541.

32 Pollock \& Maitland, op. cit. supra note 1, at 479; 3 Holdsworth, History of English Law (1923) 259; Id. at 358-359; 3 Id. at 312-313; 3 Stephen, History of the Crumunal Law of England (1883) 35-37. And see Cardozo, J., in People v Schmidt, 216 N.Y. 324, 331, 110 N.E. 945, 946 (1915) (dictum).

4 2 Bracton, De Legibus Angliae (Twiss ed., 1879), c. IV, sec. 2, pp. 277, 278: By chance, as by misfortune, when a person has projected a stone against a bird or an animal, and another person passing unexpectedly is struck and dies. But here it is to be distingurshed whether a person is employed upon a lawful or unlawful work, as if a person has projected a stone towards a place across which men are accustomed to pass and someone has been struck this is imputed to his account. But if he was employed in a lawful work, as if a master is flogging his scholar for the sake of discipline, or if when a person was casting down hay from a cart or cutting into a tree and such like, if he had taken as diligent care as he could, by looking out and by calling out, but not too slowly or in too low a voice, but in suitable time and with a loud voice, and so that if anyone were there or were coming there, he might run away and take care of himself But if he should be employed upon a lawful work, and has not used due diligence, blame shall be imputable to him. (Italics writer's.)

"At the time Bracton wrote ( (1250-1258). Bracton died 1267), homxcide had not yet been divided into its later categories of murder and manslaughter. His distinction between the two situations described in the above quotation was, therefore, probably not attended by any real difference in punishment. Perhaps it was this fact that caused Coke to classify these situations categorically as murder." Report of Law Rev Com. of N.Y. (1937) 622, n. 241.

Sayre, Mens Rea (1932) 45 Harv. L. Rev. 982-985.

'Id. at 985, note 37; Wigmore, Responsibility for Tortious Acts (1894) 7 Harv. L. Rev. 323, note 4.

In the thirteenth century an increasing emphasis upon the mental element in crime was noticeable. Bracton's book, written in 
in this instance, as in others, influenced the subsequent development of the law. At the turn of the fourteenth century pardons came to be granted as a matter of course in the case of misadventure. ${ }^{6}$ The Year Books of Edward IV's and Henry VII's reigns show that by the middle of the fifteenth century one could establish the defense by showing that he had accdentally killed another, while engaged in a lawful act. 7 However, these cases are vague as to the quality of mind and act necessary for an "accident."

Coke in his Third Institute, 8 written in the middle of the seventeenth century, places two.limitations on misadventure. The death must occur while the accused is doung a lawful act and he must be without an "evil intent." In his discussion of the second limitation Coke says:10

"Without any evil intent. If a man knowng that many people come in the street from a Sermon, throw a stone over a wall, intending to fear them, or to glve them a slight hurt, and thereupon one is killed, this is murder; for he had an ill intent, though that intent extended not to death, and though he knew not the party slam. For the killing of any by misadventure, or by chance, albeit it be not felony yet shall he forfeit his Goods and Chattels, to the intent that men should be so wary to direct their actions, as they tend not to the effusion of man's blood."

The roots of criminal negligence may be found in this discussion. Coke, who knew nothing of the term, since the concept was, as yet, unborn, labors to rationalize the limitation.

the middle of the century, undicates the change in attitude. Deeply influenced by the Roman law and the canonists, he selzed upon this shift in the principles of crimunal liability and emphasized it, often in his zeal going beyond the actual law of his day in stressing the mental requisites of criminality His book exerted a powerful influence on the subsequent law. 2 Pollock and Maitland, op. cit. supra note 1 at 477 ; 1d. at 477 , note $4 ; 2$ Holdsworth op. cit. supra, note 3 at $258-259 ; 3$ id. at 371 .

B "The result of these authorities seems to be that, in the end of the thirteenth and the beginning of the fourteenth centuries, juries were bound in cases of trials for homicide, where the defense was misadventure or self defense, to find specially that such was the case, upon which the king was bound to grant his pardon." 3 Stephen, op. cit. supra note 3 at 38 .

' 3 Holdsworth, op. cit. supra, note 3 at 313 .

${ }^{8}$ Coke, Institutes (6th ed. 1680) 56.

- Ibid. "There is an Homicide that is neither forethought nor voluntary. As if a man kill another per infortunium that is Homicide by misadventure Homicide by misadventure is when a man does an act, that is not unlawful, which without any evil intent tendeth to a man's death."

${ }^{10} \mathrm{Id}$. at 57. 
He states that the man had an "ill (evil) mtent."11 Manifestly, this was not an affirmative intent, since Coke is speaknng of homicide "that is neither forethought nor voluntary" The hypothetical case of the man who threw a stone over a wall, causing the death of a passerby, indicates what Coke had in mind. This was a highly dangerous act. The actor undoubtedly knew that it might cause the death of, or grievous bodily harm to, some person. Such wanton indifference to human life is the equivalent of an evil intent (malice), ${ }^{12}$ and punished in order that "men should be so wary to direct their actions" that they "tend not to the effusion of man's blood." Such reasoning paved the way for the decision in Hull's case, ${ }^{13}$ just ahead, and the beginnings of negligence in the criminal law.

In Hull's ease ${ }^{14}$ several workmen were building a house, which stood about thirty feet from the highway at the end of the day's work, Hull was sent to bring down a piece of timber, lyng on the second floor. He called, "Stand clear," and then threw the timber, which killed a workman. It was held not to be manslaughter as the house stood thrrty feet from the hrghway, and the defendant did what was usual for workmen to do, giving notice by his shout, so that anyone withun the range of his volce might avold the danger. ${ }^{15}$

The decision indicates the pount reached in the development of the law of misadventure, as well as the begmnings of negligence. This was a case of "accidental" killing resulting

I1 "By the second half of the seventeenth century, it was unversally accepted law that an evil intent was as necessary for felony as the act itself." Sayre, supra note 4 , at 993 .

${ }^{12}$ There is room for a difference of opmion as to whether Coke considered this to be express or implied malice. Note the discussion, pro and'con, Report of Law Rev Com., N.Y., op. cit. supra note 4, at 624, fns. 253 and 254. The difficulty of determining the matter is indicated by Stephen, op. cit. supra note 3, at 55-56.

${ }^{23} \mathrm{~J}$. Kelyng, 40 (1664).

14 Ibid.

${ }^{15}$ There is dictum in the case that if this were done in the "streets of London or other populous towns," it would be manslaughter notwithstanding the caution given by Hull. Foster, however, considers that this broad statement is subject to some limitations. "If it were done early in the morning, when few or no people are stirring, and the ordinary caution is used, I think the party is excusable. But when the streets are full that will not suffice; for in the hurry and noise of a crowded street few people hear the warning or sufficiently attend to it." Foster, Crown Law (2nd ed. 1791) 263. 
from a lawful act. The law was beginning to ask rather definitely, What limitations should be placed on the word "aceldental" in such cases? The principal case holds that even. though the act is lawful the case is not an "accident" unless the actor has taken proper precaution to avold mischief.

Hale's definition and discussion of misadventure, written In the latter half of the seventeenth century, ${ }^{16}$ show continued progress and development. In the definition ${ }^{17}$ itself he does not add a great deal to the statement of Coke, but increased particularization in the quality of mind requared is indicated by the fact that he "breaks down" Coke's limitation of "without an evil intent" into the more precise phrase, "without intention of bodily harm to any person."

However, it is in his discussion of a hypothetical case that Hale really moves forward from the definition and discussion of Coke and re-introduces a phrase ${ }^{18}$ highly important in the law of negligence.19

"If a carpenter or mason in building casually lets fall a prece of timber or stone, and kills another (it is by misadventure). But if he voluntarily lets it fall, whereby it kills another, if he gives not due warning to those that are under, it will be at least mansiaughter; quia debitan diligentiam non adhibuit." (Italics are ours.)

The phrase may be translated, "because he did not exercise due care." This is a statement of criminal negligence in a form that is clearly recognizable, there is no mistaling it.

The Idea of "due care" was now firmly entrenched in the criminal law Foster definitely includes the element in his definition of "homicide by accident".20

"This species of homicide is where a man is doing a lawful act without intention of bodily harm to any person, and using proper caution to prevent danger, unfortunately happeneth to kill." (Italics are ours).

${ }^{10}$ Hale, Pleas of the Crown (ed. of 1778) 472.

17 "Homicide per infortunium is, where a man is doung a lawful act, and without intention of bodily harm to any person, and by that act death of another ensues." Ibid.

${ }^{18}$ See page 2, supra.

The phrase is an incorporation of Bracton's idea of "due care." His influence upon English law in the suxteenth and seventeenth centuries was marked. See the discussion, 2 Holdsworth, op. cit. supra note 3 , at $\mathrm{pp} .286-291$.

${ }^{10}$ Hale, op. cit. supra note 16 , at 472 .

${ }^{20}$ Foster, op. cit. supra note 15 , at 258. The definitions of Hawkuns and Blackstone are not as satisfactory. Neither mcludes "due care" as a distinct factor. Hawkuns, Pleas of the Crown (8th ed. 1824) 85. The first edition was in 1716. 4 Blackstone, Comm. (Sharswood ed. 1870) star-page 182. 
An examination of his definition indicates that it contains three distinct factors (1) lawful act, (2) without intention of bodily harm, and (3) with proper caution to prevent danger.

The requirement that the accused must have been engaged in a lawful act to render a homicide excusable on the ground of misadventure was the source of much confusion. Coke's rule that a death caused by any unlawful act ${ }^{21}$ was murder, was extremely severe. 22 By the time of Foster the rule had been narrowed to the case where the unlawful act was also malum in $s e .23$ If it was committed in the prosecution of a felonious intention, it was murder; in the absence of such intention, it was manslaughter. ${ }^{24}$

The standard used in the early cases to determine whether the accused had used "proper caution to prevent danger" is accurately stated by Foster 25 in his discussion of $R$. v. Rampton, ${ }^{26}$ decided in 1664. The defendant found a pistol in the street and tried it with a rammer to see whether it was loaded. Satisfied that it was not, he pointed it at his wife in sport and pulled the trigger. She was killed, he was held guilty of manslaughter.

Kelyng, who reported the case, 'was not satisfied with the decision. ${ }^{27}$ Foster expressed a like dissatisfaction. ${ }^{28}$ He pointed out that the law did not require "the utmost caution that could be used." A "reasonable precaution," such as was "usual and

a1 "If the act be unlawful, it is murder

If he had shot at a Cock or Hen, or other tame fowl of another man's, and the Arrow by mischance had killed a man, this had been murder, for the act was unlawful." Coke, op. cit. supra note 8, at 56. Turner, The Mental Element in Crimes at Common Law'(1936) 6 Camb. I. J. 31,42 .

${ }^{22}$ Stephen considered Coke's doctrine to be "monstrous." 3 Stephen, op. cit. supra note 3 , at $74-75$.

${ }^{3}$ Foster, op. cit. supra note 15, at 258-259.

24 Ibld. Although Foster's modification of Coke's doctrme lessened its stringency in part, the rule remained severe. The following comment by Foster (a modification of the illustration used by Coke in note 21, supra) will show this. "A shooteth at the poultry of $\mathrm{B}$, and by accident killeth a man; if hus intention was to steal the poultry, which must be collected from curcumstances, it will be murder by reason of that felonious intent." This appears shockung in the light of modern rules of crimunal liability.

${ }^{25}$ Foster, op. cit. supra note 15 , at 264.

$\approx$ Kelyng 41 .

${ }^{2}$ Ibld., see footnote.

${ }^{25}$ Foster, op. cit. supra note 15, at 264. 
ordinary in like cases" 29 was the standard. It seemed to hm that the accused in the Rampton case had satisfied this standard of care.

It is apparent that ordinary negligence was sufficient for cruminal liability at this time $;^{30}$ the requirement of gross negligence was a later development.

The analysis and discussion of Foster carried the development of criminal negligence to the latter part of the eighteenth century The requrement of "due care under the crrcumstances," operating as a limitation on homicide by misadventure, had become an established part of the law of erimes. It is upon this background that the modern cases are projected.

${ }^{2}$ See the discussion of Sir John Chichester's Case, 1 East, Pleas of the Crown (1803) 268-269. "It is sufficient that a reasonable precaution, what is usual and ordinary in like cases, be taken; such as hath been found by long experience in the course of human affaurs to answer the end." Id. at 266-267.

${ }^{30}$ See Report of Law Rev. Com., N.Y., op. cit. supra note 4, at 759-761 and authorities cited; Davis, The Development of Negligence as a Baszs for Criminal Lrability in Crımınal Homicıde Cases (1938) $26 \mathrm{Ky}$. L. J. 209, 217. 


\section{PART II}

\section{THE NATURE AND QUALITY OF CRIMINALLY NEGLIGENT CONDUCT}

\section{SECTION 2. FUNDAMENTAL PROBLEMS IN CRIMINAL NEGLIGENCE}

What has been the effect of the early development of crimlnal negligence upon the modern cases? This is naturally the first questron that comes to one making a study of the subject. Has the original analysis been followed, with modifications as needed, or has it been largely repudiated?

What is the standard of eare that must be used by the accused in order that he may be found to have taken "the proper caution to prevent danger"'? Is the lawfulness or unlawfulness of the act still a basis for dividing the cases? What is the quality of mind required today,-Is negligence objective or subjective?

One may answer these questions in a general way by saying that throughout all the modern cases there runs a constant thread of terminology and reasoning bearing unmistakable knship to the terminology and reasoning in the early cases and texts. However, certain changes have been drastıc. The discussion which follows will indicate these and attempt to point out others which seem necessary

Negligence is chrefly important in murder, manslaughter, and assault and battery Consequently, these will be the only crimes discussed. Certain problems are fundamental in all of these. Suppose, for example, that it is decided that negligence is objective rather than subjective. How can this conclusion be reconciled with the fundamental concept of the criminal law that some type of mens rea is a necessary element in the imposition of erimmal liability?

Other problems are peculiar to only one or two of the crimes mentioned. The basis of liability in murder and manslaughter must be differentiated. A more difficult task lies in marking the line, admitted to be shadowy, between criminal and civil negligence. Is there such a thing as a negligent battery? Neither the courts nor the text-writers are in accord on these 
matters. Conflicting authorities must be studied and solutions suggested.

Certain questions have been excluded from the discussion, although they are often found as contributing factors in negligence cases. Drunkenness is one of these. In many cases the defendant, who drove a car or handled a gun negligently, was also drunk or had been drinking. In such cases, although drunkenness and negligence are related, drunkenness contains so many separate problems that to consider them and therr relation to negligence would unduly prolong the paper. Consequently, a discussion of thes question has been omitted, except on the case of the negligent murder where intoxication rasses a special problem. Similar considerations have led to the exclusion of such questions as causation, Ignorance or mistake of law or fact, and the responsibility of corporations or others for the acts of employees.

One of the most difficult and controversial problems in the law of negligence relates to the standard of care which shall be used in determining whether the accused has sufficiently met the requirement that he must have taken proper caution to prevent danger in order to avord criminal liability

Two standards have been formulated by the courts and legislatures in negligence cases. The first, gross negligence, is the standard in the majority of jurisdictions. ${ }^{31}$ Gross negilgence has been defined as "such a departure from what would be the conduct of an ordinarily prudent man under the same crrcumstances as to furnish evidence of that indifference to consequences which in some cases takes the place of crmmal intent."32 The other, the tort standard applied to crimmal law, is followed in a few jurisdictions. It may be defined as "the degree of care which an ordinarily prudent man would use under like crrcumstances." 33 These two standards will be discussed in reverse order.

The standard in each state will be found summarized in an appendix to an article, Riesenfeld, Negligent Homicrde-A Study in Statutory Interpretation (1936) 25 Calif. L. Rev. 1, 37.

${ }^{32}$ Fitzgerald v. State, 112 Ala. 34, 20 So. 966 (1895).

*Harper, Torts (1933) sec. 69 . Nail v. State, 33 Okla. Cr. 100, 242 Pac. 270 (1926) State v. Gilliam, 66 S.C. 419 , 45 S.E. 6 (1903); Young v. State, 120 Tex. Cr. Rep. 39, 41, 47 S.W (2d) 320,321 (1932) (note Tex. Stat. (Vernon, 1936) (Penal Code) c. 14, art. 1233); Clemens v. State, 176 Wis. 289, 185 N.W 209 (1921). 


\section{SECTION 3. THE TORT STANDARD OF CARE}

\section{A. Jurisdictions Which Contain Decisions Applying It}

Although some of the early commentators did not attempt to formulate a standard, ${ }^{34}$ numerous statements in early common law discussions indicate that criminal negligence in manslaughter at that time meant merely lack of ordinary care. ${ }^{35}$ Although the majority of jurisdictions in the United States have repudiated that standard today, decisions in several states are commonly cited as subseribing to the tort standard of care.

\section{Texas}

Texas is outstanding among the jurisdictions that have accepted the tort standard of care. The tort standard has been adopted by statute in that state in the case of homicide by negligence. The provision is as follows .36

"The want of proper care and caution distingurshes this offense from excusable homicide. The degree of care and caution is such as a man of ordinary prudence would use under like curcumstances."

Eighteen years ago the court construed this provision in Haynes $\nabla$. State, ${ }^{37}$ holding that "the degree of care and caution which a man of ordinary prudence would use under like curcumstances is the statutory definition in such cases" and therefore the standard of eare to be followed.

The court affirmed this interpretation in 1932 and added. "It may be doubted if there is greater unanmity among the courts of all jurisdictions upon any one thung than in the general definition of negligence, as being a failure to do what a man of ordinary care and prudence would do under the same or like circumstances." 38

\footnotetext{
34 Hale discussed specific cases where the accused was held guilty of involuntary manslaughter because of "lack of due care" but made no attempt to define it. Hale, op. cit. supra note 16, at 471-478.

${ }^{35}$ See the text and footnotes, supra, at pp. 6-7. Indeed, Foster, an acknowledged authority, remonstrated against certain contemporaneous manslaughter convictions based, it seemed to hum, upon a standard of care that was higher than "ordinary care" under the circumstances. Foster, op. cit. supra note 15, at 263-265.

${ }^{36}$ Tex. Stat. (Vernon, 1936) (Penal Code) c. 14, art. 1233.

${ }^{37} 88$ Tex. Cr. Rep. 42, 224 S.W 1100 (1920).

${ }^{33}$ Young v. State, 120 Tex. Cr. Rep. 39, 41, 47 S.W (2d) 320, 321 (1932)
} 
This is an interesting assertion in view of the fact that there is a decided lack of unanimity among the courts in applying this standard in crimınal cases. The authorities cited in support of the statement are civil cases. Great unanmity among the courts of all jurisdictions does prevail in the interpretation of negligence on that side of the docket. Apparently the court is emphasizing the fact that it has taken over the civil standard completely in the case of negligent homicide.

\section{South Carolina}

There is a line of cases in South Carolina subscribing to the rule that in manslaughter by the negligent use of a deadly weapon the standard is that of ordinary care under the cur cumstances, and that to support a verdict a lack of care amounting to recklessness or gross negligence is not necessary The rule was first promulgated in State v. Gilliam ${ }^{39}$ and that case remains the leading decision in the series. In State v. Han$a h a n^{40}$ the rule was extended to the negligent operation of automobiles. Another line of decisions in the state is more or less at variance with the above rule and with the cases which support it. The first of these is State $\mathrm{v}$ Davrs. ${ }^{41}$ That case held that simple negligence would not support a conviction of manslaughter. It is apparent from the opmion that the court

s 66 S.C. 419, 45 S.E. 6 (1903) The defendant was tried for the murder of his wife. He sought to explaun the killing by showing that it happened unintentionally in a playful tussle between them for the possession of a pistol. The trial judge charged on negligent homicide, adopting the tort standard of care. Girliam excepted to the charge on the ground that it was in conflict with the law as to manslaughter by negligence. The appellate court overruled the exception.

Seven years later the principles of law in relation to the negligent handling of a gun enunciated in State v. Gilliam were affirmed in State v. Revels, 86 S.C. 213,68 S.E. 523 (1910). Accord: State v. McCalla, 101 S.C. 303, 85 S.E. 720 (1915). In the McCalla case Watts, J., dissented on the ground that gross negligence, not ordinary negligence, was necessary to convict. In State v. Tucker, 86 S.C. 211, 68 S.E. 523 (1910), the court's instructions were substantially the same as in the Gilliam case. Tucker excepted to the charge. The appellate court reaffirmed the instructions given in that case and overruled the exceptions in the instant case. Accord: State $v$ Badgett, 87 S.C. 543,70 S.E. 301 (1911)

${ }^{10} 111$ S.C. 58,96 S.E. 667 (1918)

4128 S.C. 265,122 S.E. 770 (1924). The defendant claumed that the injury which caused the death of the deceased, his wife, was caused when he stumbled over a charr in attempting to carry her to a bed when she fell in an epileptic seizure. 
intended to follow the majority rule, which requires gross negligence. That rule was quoted verbatim from Corpus Juris, ${ }^{42}$ although the court placed certain limitations upon it. ${ }^{43}$

State $\mathrm{v}$ Williams ${ }^{44}$ was the next decision in this series. In that case the court instructed. "It is manslaughter when it is more than a mere accident." This was held to be reversible error. The appellate court pointed out that the instruction included "ordinary care and negligence," which the case of: State $\checkmark$ Davis had held to be insufficient.

A choice between, or a reconciliation of, the conflicting principles enunciated in State $\nabla$ Gilliam and State v. Davis was mnevitable. The case of State $v$. Qunck, ${ }^{45}$ the last in the series supporting State v. Gilliam, attempted to meet the issue. The defendant was indicted for murder and found guilty of involuntary manslaughter. She admitted that she shot the deceased with a pistol, a deadly weapon, but pleaded accidental homıcide. The court reviewed in detail the South Carolina decisions, reaffirmed its position that the standard of care in such cases is the care that an "ordinarily careful" man would use, and concluded that it knew of no decision of the court changing that rule. So, undoubtedly, State v. Gilliam is still law in South Carolina. However, the defendant had relied upon State $\mathrm{v}$ Daves and it was necessary to differentiate the two cases. Thrs the court did by pointing out that the use of a deadly weapon was not involved in the Davis ease.46

29 Corpus Juris (1922) 1154. However, had the justice examuned carefully the footnotes to the same page from which he quoted, he would have found State v. Gilliam, 66 S.C. 419,45 S.E. 6 (1903), cited as definung negligence as the want of ordinary care.

4s "There may be curcumstances connected with the homicide, such as the situation of the parties, the character of the instrumentality carelessly handled, and others, which may convert an act, otherwise one of simple negligence, into gross or reckless negligence, and justify a conviction of manslaughter or even murder; but it was manifest error to charge that in every instance, regardless of the curcumstances, an act of ordinary negligence will constitute manslaughter." State v. Davis, 128 S.C. 265, 122 S.E. 770, 771 (1924)

\$1 131 S.C. 294, 127 S.E. 264 (1925) Accord: State v. Cameron, 137 S.C. 371 , 135 S.E. 364 (1926) See the dissenting opmion in State v. Sussewell, 149 S.C. 128,146 S.E. 697 (1929).

${ }^{45} 168$ S.C. 76,167 S.E. 19 (1932).

10 State v Hanahan, 111 S.C. 58, 96 S.E. 667 (1918), which extended the rule in the Gilliam case to the negligent operation of an automobile, was not mentioned in the decision. The Hanahan case seems to be the only automobile case, involving a conviction of manslaughter for negligent homicide, that has reached the appellate court. 
The result seems to be that ordinary negligence in dealing with a gun or an automobile (dangerous agencies) is sufficient to support a verdict of manslaughter in South Carolina. ${ }^{47}$ In all other situations ${ }^{48}$ gross negligence is required.

\section{Oklahoma}

In Oklahoma it is manslaughter in the second degree to kill a human being by "culpable negligence." 49 The tort standard of care has been adopted in the interpretation of "culpable negligence" as used in this statute. ${ }^{50}$ Thus, in Herndon v. State, 51 the court in defining the degree of negligence sufficient to convict of manslaughter in the second degree sard. "Culpable negligence is the omission to do something which a reasonable and prudent person would do, or the doing of something which such a person would not do under the crrcumstances surrounding the particular case."

There 1s, however, a curious anomaly in a number of the Oklahoma decisions. Although the tort standard of care is used in defining "culpable negligence", as used in the statute, the court has confused it with gross negligence. Herndon v. State $e^{\mathbf{5 3}}$ will illustrate. In that ease the tort standard of care was applied. The court, however, quoted from a case, and apparently

${ }^{47}$ This rule should be compared with the quotation from State $\nabla$. Davis, 128 S.C. 265, 122 S.E. 770 (1924), cited note 43, supra, and Held v. Com., $183 \mathrm{Ky} .209,208 \mathrm{~S} . \mathrm{W} 772$ (1919). The Davis case suggests and the Held case holds that the want of ordinary care is gross negligence where a gun is being handled in the presence of others, or an automobile is being driven on a crowded thoroughfare in a city. It is submitted that South Carolina is really applying the standard of gross negligence in all cases, since the want of ordinary care with a dangerous instrumentality under such curcumstances amounts to gross negligence. See the discussion, infra.

And see the instruction which the appellate court of South Carolina affirmed in State v. Quick, 168 S.C. 76, 167 S.E. 19, 20 (1932).

${ }^{2}$ Such, for example, as the situation in State v. Davis, 128 S.C. 265,122 S.E. 770 (1924), cited supra note 41 .

ss "Any killing of one human being by the act, procurement or culpable negligence of another, which under the provisions of this chapter is not murder, nor manslaughter in the first degree, nor excusable nor justifiable homicide, is manslaughter in the second degree." Okla. Comp. Laws (1931) sec. 2228.

${ }^{50}$ Kent v. State, 8 Okla. Cr. 188, 126 Pac. 1040 (1912), Pamplin v. State, 21 Okla. Cr. 136, 205 Pac. 521 (1922), Clark v. State, 27 Okla. Cr. 11, 224 Pac. 738 (1924), Romines v. State, 45 Olkla. Cr. 40, 281 Pac. 310 (1929). Note (1930) 28 Mich. L. Rev. 933, 934.

38 Okla. Cr. 338, 261 Pac. 378 (1927).

Id. at 379.

ss Ibid. 
adopted a statement to the effect that the law as regardful of human life and if one is grossly and wantonly reckless in exposing others to danger, he will be held responsible for resulting injuries. The court was confusing the two standards and apparently trying to use both, which is an impossibility

The court was in even greater error in Nail v. State. 54 The case definitely adopts the tort standard. However, the opmion apparently makes a distinction of degree between clvil and crumnal negligence.

Such inconsistencies in the Oklahoma decisions are hard to explain. It as believed, however, that the state is definitely committed to the tort standard of care in the interpretation of "culpable negligence" and that such allusions to the other standard are inadvertent.

\section{Wisconsin}

Clemens $\mathrm{v}$ State, ${ }^{5 \overline{5}}$ a Wisconsm case, is commonly eited as illustrative of the minority rule. This decision involved the interpretation of a statute which made the killing of a human being by culpable negligence manslaughter in the fourth degree. The appellate court held that "culpable negligence" as used in this statute meant "ordinary negligence" "Ordinary negligence" as defined by the court was a "want of that care and prudence that the great mass of mankmd exercises under the same or similar erreumstances." 56

It is important to note, however, that in 1929 the word "gross" was inserted in the statute in lieu of "culpable" by legislative action. ${ }^{57}$ Following that action the appellate court, in State $\mathrm{v}$ Whatley, ${ }^{58}$ held that under the present statute the defendant's conduct must be more reprehensible than mere want of ordinary care, "in that there must be on his part either a willful intent to injure, or that reckless and wanton disregard of the rights and safety of another or his property, which the law deems equivalent to an intent to injure." 59 It may be

33 Okla. Cr. 100, 242 Pac. 270 (1926). See the comment on this case, Riesenfeld, supra note 31 , at 39 .

${ }^{55} 176$ Wis. 289,185 N.W 209 (1921)

${ }^{\mathrm{B}} \mathrm{Id}$. at 212.

${ }^{87}$ Wis. Stat. (1929) sec. 340.26 .

ss 210 Wis. 157, 245 N.W 93 (1932).

${ }^{\text {E }}$ Id. at 96. 
concluded that Clemens v. State and the tort standard of care have been definitely repudiated in Wisconsm by this statute. ${ }^{60}$

\section{Missourn}

There are a number of eases in Missourl which adopt the tort standard of care in defining "culpable negligence" as used in a statute on fourth degree manslaughter. ${ }^{61}$

The first case of importance was Emery v. State.62 The definition used by the court ${ }^{63}$ was lifted bodily from Shearman \& Redfield on Negligence, an authority on crvil negligence. However, the decision had a far-reaching effect on subsequent cases.

The tort standard of care as enunciated in the Emery case was affirmed in State v. Horner 64

In State $\mathrm{v}$ Wersman," 65 the phrase, "by reason of which omission or act another person is directly endangered in life or bodily safety" was added to the definition. Two crvil cases were among the supporting authorities. ${ }^{66}$

Then came State v. Millin, 67 which completely repudiated the standard of care as enunciated in the earlier decisions. In instructing the jury the trial court used the definition of culpable negligence adopted in the Emery case and aftirmed in the series of subsequent decisions just discussed. The appellate court held, however, that such instructions fell short of sub-

${ }^{\infty}$ Christie v. State, 212 Wis. 136, 248 N.W 920 (1933). See Gausewitz, Work of the Wisconsin Supreme Court: Crmmnal Law (1933) 9 Wis. L. Rev. 21.

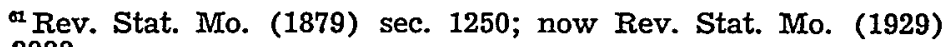
sec. 3988 .

62 78 Mo. 77 (1888).

as "Culpable negligence is the omission to do something which a reasonable, prudent and honest man would do, or the doing something which such a man would not do under all the curcumstances surrounding each particular case." Id. at 80 .

of 266 Mo. 109, 180 S.W 873 (1915). The court cited Wharton on Homicide as supporting authority. It is true that Wharton does support the tort standard of care in section 445 but he inconsistently adopts the requrement of gross negligence in section 446 . Wharton, Homicide ( $3 \mathrm{rd}$ ed. 1907) secs. 445, 446.

${ }^{\infty} 256$ S.W (Mo. Sup.) 740 (1923).

${ }^{\infty 6}$ Jackson v. Bell Tel. Co., 281 Mo. 358, 219 S.W 655 (1920), Gilbert v. Hilliard (Mo. App.) 222 S.W 1027 (1920).

" 318 Mo. 553, 300 S.W 694 (1927). 
mitting to the jury a correct definition of culpable negligence. The court said: 68

"The definition of culpable negligence heretofore approved in State $v$. Weisman and other cases is mere negligence, such as would be actionable in a civil suit, whereby life or limb is directly endangered. Culpable negligence, as used in,our statute means something more than this."

The court land down the rule that before a person could be convieted of manslaughter by culpable negligence under the statute it was necessary not only that death ensued from the negligent act or omission but "there must be facts and eircumstances in evidence tending to prove that such, person was actuated at the time by a reckless disregard of the consequences of his act." 69

The standard of care in Missour has been gross negligence, sunce the Millin case. In State v. Baublits, ${ }^{70}$ decıded in 1930, the court stated its present position on the rule quite clearly

"There is a marked distinction between simple or ordinary negligence, giving one a right of action for damages, and culpable negligence, rendering one guilty of a criminal offense. Culpable negligence is tantamount to gross carelessness or recklessness incompatible with a proper regard for human life."

It is submitted that the tort standard of care is used in only four states in defining crimunal negligence. It has been adopted by statute in Texas in the case of negligent homicide and by the courts in Oklahoma in the interpretation of "culpable negligence" as used in a statute on manslaughter in the second degree. In addition, the courts in Michngan and Califorma have construed certam negligent homucide statutes in those jurisdictions as requiring no more than ordinary negligence. ${ }^{70^{*}}$ All other jurusdictions have repudiated it with the exception of South Carolina, which, although it subscribes to the tort standard in the case of certain dangerous agencies, is, in reality, applyng a standard which amounts to gross negligence. ${ }^{71}$

B. Reasons for Its Rejection in the Majortty of States

What are the reasons for the repudiation of the early common law standard of "ordinary care" by most jurasdictions"

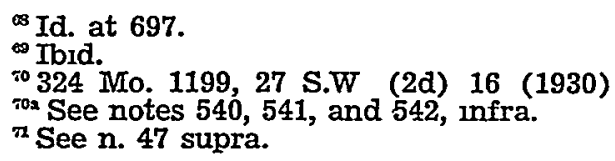


The rejection of the tort standard seems to be based, primarily, upon the reason, first suggested by Foster, 72 that to make criminal liability for manslaughter coincıdent with crvil liability for negligence would be too harsh. It would raise the threat of crimunal liability upon every member of the community, any one of whom might at any time find himself in the circumstance of having committed an act of ordinary negligence. 73 "Accidents of thrs lamentable kind may be the lot of even the wisest and best of mankand. "'74

The following cases will illustrate. A, a law-abıding citizen, usually prudent and careful in his conduct, is driving his automobile slowly down the street. He casually turns to wave to a friend whom he sees on the sidewalk. The car hits a person and fatally injures him, an injury which would not have occurred if A had not turned his head.

In another case, $B$ is driving his ear through the mid-town busmess section at a rate of speed likely to be dangerous to

"I "I cannot help sayng, that the rule of law I have been considering in this place, touching the consequence of taking or not taking due precaution, doth not seem to be sufficiently tempered with mercy. Manslaughter was formerly a capital offense, as I shall hereafter show; and even the forfeiture of goods and chattels upon the foot of the present law is an heavy stroke upon a man, guilty, it is true, of an heedless incautious conduct, but in other respects perfectly innocent. And where the rigour of law bordereth upon injustice, mercy should, if possible, interpose in the administration. It is not the part of judges to be perpetually hunting after forfeitures, where the heart is free from guitt. They are mmisters appointed by the Crown for the ends of publick justice; and should have written on their hearts the solemn engagement his Majesty is under 'to cause law and justice in mercy to be executed in all his judgments.'

"I have been the longer upon this case, because accidents of this lamentable kind may be the lot of the wisest and the best of mankind, and most commonly fall amongst the nearest friends and relations; and in such a case the forfeiture of goods, rigorously exacted, would be heaping affliction upon the head of the afflicted, and galling an heart already wounded past cure. It would even aggravate the loss of a brother, a parent, a child, or wife, if such a loss under such circumstances is capable of aggravation." Foster, op. cit. supra note 15 , at $264-265$.

${ }^{73}$ Report of Law Rev. Com., N.Y., op. cit. supra n. 4, at 247. Cf: "It would seem that, according to the rationale of the case, in our complex state of society, where there are so many instrumentalities which, if not carefully used will cause death, the threat of civil liability is not enough to act as a deterrent, and that the sanctions of society must be imposed on those who do not use reasonable care in order that the citizens of the state may be reasonably free from bodily harm at the hands of its careless individuals." Davis, supra note 30 , at 223 .

"Foster, op. cit. supra n. 15, at 264. 
human life and safety The car is full of young people, all slightly under the influence of liquor, hilarious and gay The driver, without slowing down, turns and waves to a young friend on the sidewalk. The car hits a man and kills hrm.

Should the eriminal law punish one of these men and not the other? Both were guilty of incautious conduct and in each case it led to the death of an innocent person.

A is guilty of ordinary negligence and therefore liable eivilly To adopt the tort standard in crimes would, of necessity, result in holding the defendant guilty in the case of every crime for which a parallel tort exists. So, under the tort standard, A would also be subject to erimmal liability However, it is to be doubted whether he is guilty of gross negligence. 75 B is guilty of gross negligence.

The difference in the two cases lies in the difference in the degree of negligence. This difference in degree has two important aspects to the general public and to those who administer the criminal law.

First, the probability of harm is much greater in the second case. It is not so likely that an accident will happen in the first case, the danger of societal harm is slight. An accident is likely to happen under the crrcumstances in the second case, the danger of societal harm is great. ${ }^{76}$

Second, any good citizen is likely to find himself in A's situation at any time. When this is considered in connection with the fact that accidents under such crrcumstances are rather unlikely, there is strong argument for refusing to impose crimmal liability

On the other hand, most good citizens do not consider it likely that they will find themselves in circumstances such as $B$ 's at any time. 77 When this is considered in connection with

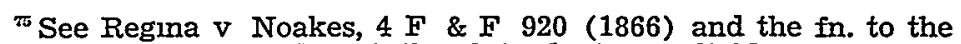
case, where it is stated that the defendant was liable in tort for his negligent act. See also, Rex v. Greisman (1926) 4 D.L.R. 738, 741.

"See the discussion, Wechsler and Michael, A Rationale of the Law of Homrcide (1938) 37 Col. L. Rev. 701, 721-723; id. at 742-751.

"In connection with the discussion in the text consider the following statement from Rex v. Bateman, 19 Cr. App. R. 8 (1925) "To establish crimunal liability the facts must be such that, in the opimion of the jury, the negligence went beyond a mere matter of compensation between subjects and showed such disregard for the 
the fact that danger of societal harm is great under such errcumstances, there is strong argument for ermmnal liability

A number of other considerations have influenced the courts and legislatures in their refusal to adopt the tort standard of care in criminal negligence. It seems to be generally considered that its adoption would not materially improve the carefulness of the majority of individuals. ${ }^{78}$ Therefore, the deterrent effect of the mereased liability would not be commensurate with the suffermg and humiliation inflicted upon those convicted and their families under the higher standard.

It is believed that juries would not convict even though the tort standard were the law, especially if imprisonment were involved in a verdict of guilty The only effective alternative to imprisonment is a fine. What would that add to the present liability for money by way of compensation to the injured party or his personal representative? If the payment of money will deter the potential wrongdoer, his civil liability in tort will have sufficient deterrent effect.

life and safety of others as to amount to a crume against the State and conduct deserving punishment." (Italics are writer's). The conduct of $B$ falls within this rule; the conduct of $A$ does not.

is "The requrement of 'gross' negligence rather than ordinary negligence in manslaughter cases seems satisfactory, for crimunal punishment does not often deter ordinary negligence, and the deterrence of such negligent acts would seem to be the only reason to support crimunal punishment." Note (1930) 28 Mich. L. Rev. 933, 934 . 


\section{SECTION 4. THE NEED FOR A DEFINITION OF CRIMINAT NEGLIGENCE}

The rejection of the tort standard of care $^{79}$ presents the critical problem of defining the extra degree of negligence reqursite to crimual liability The courts have experienced great difficulty in solving this problem.

There are those who believe that a satisfactory definition of the term as used in the crimmal law is impossible. The footnote to Regrna $\vee$. Noakes ${ }^{80}$ is the classic example of this defeatist attitude

"The case is certainly of some practical importance as affording a remarkable illustration of that which it has too often been said cannot be defined, and can only be defined by means of illustrations, viz:-culpable or criminal negligence. It is impossible to define it, and it is not possible to make the distinction between actionable negligence and crmmal negligence intelligible, except by means of illustrations drawn from actual judicial opmions." ${ }^{81}$

As eapable an authority as Stephen states" that no one is able to say how much more carelessness is required to create crummal liability than c1vil: It is "more" but no one can say "how much more" "No rule exusts in such cases. It is a matter of degree determined by the view the jury happen to take in each particular case." 82 p. 16.

See the discussion, supra, pp. 10-19. Note the summary on

${ }^{50} 4$ F \& F 920, 176 Eng. Rep. 849 (1866).

${ }^{81}$ Id. at 921 .

s: "In order that homicide by omission may be criminal, the omission must amount to what is sometimes called gross, and sometimes culpable negligence. There must be more, but no one can say how much more, carelessness than is required in order to create a clvil liability. For instance, many railway accidents are caused by a momentary forgetfulness or want of presence of mind, which are sufficient to involve the railway in civil liability, but are not sufficient to make the railway servant guilty of manslaughter if death is caused. No rule exists in such cases. It is a matter of degree determined by the view the jury happen to take in each particular case." 3 Stephen, op. cit. supra n. 3, at 11.

"In some cases the attempt to elucidate the principles to be applied is abandoned and the question of what is to be done with the person in the dock is handed over to the jury who are left, without any proper guxdance, to come to a decision under any chance influences or prejudices that may happen to be operating at the moment in their minds-even such as may be aroused by the personal appearance of the prisoner, his calling, demeanor, or social position." Turner, supra note 21 , at 40 . 
Acqurescence in Stephen's view that the extra amount of negligence necessary to create crummal liability is a matter of degree, incapable of precise definition, and that therefore whether it exists to such a degree in a particular crimunal case is largely a matter for the jury is found in a number of .cases. ${ }^{83}$

Such a solution to the problem must be rejected as untenable. It is doubtful whether those who have advocated it realize its implications. On its face, it advocates going practically the whole way and sumply askung the jury whether the defendant's conduct ought to be classed as crmminal under the facts of the particular case.

\section{A. The Reuation of Criminal Procedure to the Substantive Problem}

This requires facing the question of the jury's function in crimmal cases. In a few states the jury is the judge of the law as well as the facts, ${ }^{84}$ but in most jurisdictions all questions of law are decided by the court ${ }^{85}$ and all questions of fact by the

s "The degree of negligence in such a case that would make a man criminally responsible can hardly be defined. It is not a slight failure in duty that would render him crumnally negligent, but a great failure undoubtedly would. The line between the two extremes is hard to define, and is a question that must be left to a great extent in each individual case to the common sense of the trial jury. It is for them to determine whether or not the degree of failure of duty is in fact crimmal." Stehr v. State, 92 Neb. 755, 139 N.W 676 (1913). Accord: Hampton v. State, 50 Fla. 55, 39 So. 421 (1905), State v. Lester, 127 Minn. 282, 149 N.W 297 (1914)

ss For example, in the following statutes it is provided that the jury shall be judges of the law and the facts: Ga. Penal Code (1933) sec. 1059; III. State Bar Stat. (1935) c. 38, sec. 764; La. Code Cr. Pr. (1929) art. 383. See Clark, Crum. Proc. (2nd ed. 1918) 542-546. "We have said that, being judges of the law and the fact, the jury are not bound by the law, as given to them by the court, but can assume the responsibility of deciding, each juror for himself, what the law is. If they can say, upon therr oaths, that they know the law better than the court, they have the power so to do. If they are prepared to say that the law is different from what it is declared to be by the court, they have a perfect legal right to say so and find the verdict according to their own notions of the law. It is a matter between their consciences and their God, with which no power can interfere The jury were not bound to take the law as 'IaId down' to them by the court, but had the undoubted right to decide it for themselves, and in refusing so to declare the court erred." Fisher $v$ The People, 23 IIl. 218, 231 (1859). See article, Harker, The Illinous Juror in the Trial of Criminal Cases (1911) 5 nll. L. 'Rev. 468.

${ }^{85}$ It is provided by statute in a number of states, however, that on a trial for libel, the jury has the right to determme the law and the facts. See A.L.I. Code of Crm. Proc., page 964. 
jury 86 The jury applies the law as given to it by the court 87 to the facts. The court cannot evade its responsibility to $\mathrm{m}$ struct on the law of the case by passing the problem to the jury

Nor has the court satisfactorily fulfilled this responsibility unless the instructions which it gives actually illumine the law for the jury If the jury is to be intelligently guided by the instructions, it is necessary that the court state the law clearly. This means not only that it be stated in language that the jury can understand, but also that it be stated, as nearly as possible, with certanty. The less precise the judge's mstructions, the wider the law-makng function of the jury Judges realize that instructions on criminal negligence have not been sufficiently precise. However, the great majority of them have no intention of leaving the substantive question of negligence to the jury

Moreover, even though judges were to evade their responsibility in the case of the instructions and pass the negligence Issue to the jury, their problem would not be solved.

The question of negligence arises in other ways. The defendant may demur to the indictment 88 or information 89 or move to quash ${ }^{90}$ on the ground that it does not charge an offense, one element of which is the crimunal negligence of the defendant. The court must decide whether, as a matter of law, negligence is alleged.

${ }^{80}$ Id. at 962-964; Clark, op. cit. supra note 84, at 543-546. In Sparf and Hansen v. U. S., 156 U. S. 51 (1895), the question is considered at great length and numerous cases are reviewed.

${ }^{87}$ Even in those jurisdictions where the jury is judge of both law and facts, the judge is not released from his duty and obligation of unstructing as to what the law zs. The jury has the power to determine the law over the head of the court, but that does not prevent the court from telling the jury what the law is and the importance of following it as enunciated.

${ }^{8 s}$ State v. Hardister and Brown, 38 Ark. 605 (1882), Hayes V. State, 138 Ga. 457 , 75 S.E. 523 (1912); State v. Lester, 127 Minn. 282, 149 N.W 297 (1914).

${ }^{\circledast}$ Mayse v. State, 38 Okla. Cr. 144, 259 Pac. 277 (1927), Ansley v. State, 44 Okla. Cr. 382, 281 Pac. 160 (1929); Rommes v. State, 45 Okla. Cr. 40, 281 Pac. 310 (1929)

${ }^{80}$ Cannon v State, 91 Fla. 214, 107 So. 360 (1926), People v. Falkovitch, 280 IIl. 321, 117 N.E. 398 (1917), State v. Bailey, 107 Kan. 741, 193 Pac. 354 (1920). In State v. Whatley, 210 Wis. 157, $245 \mathrm{~N} . \mathrm{W} 93$ (1932) the State appealed from an order sustaining the defendant's plea in abatement to the information. 
The question of negligence presents itself in a number of ways in connection with the evidence. During the course of the trial the question may arise as to whether certain proposed testimony tends to show criminal negligence. 91 In some states the defendant may demur to the evidence. ${ }^{92}$ Or he may contend that it is insufficient to authorize the submission of the case to the jury ${ }^{93}$ After a verdict for the state, the defendant may move for a new trial on the ground that the evidence is insufficient to support the verdict. 94

After conviction, the defendant may again test the sufficiency of the indictment or information ${ }^{95}$ or reach other defects apparent on the face of the record ${ }^{96}$ by a motion in arrest of judgment. If there is an appeal, the scene of action shifts to the appellate court which will either approve or disapprove of the trial judge's.action in dealing with the negligence issue.

A glance back at the varıous stages where the issue of negligence may arise in the trial of a criminal case containing that factor indicates the futility of any attempt to evade the substantive problem of erimmal negligence by the trual judge. It may come to the surface at several places in the proceedings. ${ }^{97}$

${ }^{\circ 1}$ People v. Barnes, 182 Mich. 179, 148 N.W 400 (1914) 'People v. Harrıs, 214 Mich. 145, 182 N.W 673 (1921), State v. Vines, 93 N.C. 493,53 Am. Rep. 466 (1885), State v. Miller, 119 Ore. 409 , 243 Pac. 72 (1926); State v. Ramos, 159 Wash. 599, 294 Pac. 223 (1930).

State v. Weisman, Mo. $256 \mathrm{~S} . W 740$ (1923) State v. Winkler, 309 Mo. 28, 273 S.W 1040 (1925) (dictum), State v. Scheufler, Mo. 285 S.W 419 (1926), State v. Sawyers, 336 Mo. 644, 80 S.W (2d) 164 (1935).

${ }^{03}$ State v. Horner, 266 Mo. 109, 180 S.W 873 (1915), State v. Millin, 318 Mo. 553, 300 S.W 694 (1927), State v. Murphy, 324 Mo. 183, 23 S.W (2d) 136 (1929) State v. Melton, 326 Mo. 962, 33 S.W (2d) 894 (1930), State v. Rountree, 181 N.C. 500, 106 S.E. 669 (1921). See State v. Watson, 216 Mo. 420, 115 S.W 1011 (1909).

${ }^{\circ}$ Foy v. State, 40 Ga. App. 617, 150 S.W 917 (1929), Dunville v. State, 188 Ind. 373, 123 N.E. 689 (1919), State v. Kuum, 55 Mont. 436, 178 Pac. 288 (1919), Ford v. State, 71 Neb. 246, 98 N.W 807 (1904), State v. Rountree, 181 N.C. 500, 106 S.E. 669 (1921), Herndon v. State, 38 Okla. Cr. 338, 261 Pac. 378 (1927), Goodman v. Com., 153 Va. 943 , 151 S.E. 168 (1930)

${ }^{20}$ Madding v. State, 118 Ark. 506, 177 S.W 410 (1915), People v. Buddenseick, 103 N.Y. 487, 9 N.E. 44 (1886); Reddick v. State, Tex. Cr. App. 47 S.W 993 (1898)

${ }^{2}$ Overby v. State, 115 Ga. 240,41 S.E. 609 (1902).

${ }^{n}$ Leon Green points out that the negligence issue may come to the surface at any one or more of five possible stages in a civil case. At four of these it demands the judgment of the judge; at the other, that of the jury. Green, The Negligence Issue (1928) 37 Yale L. J. 1029, 1031. 
Even though the judge might desire to shun his responsibility in the case of the instructions and, as a practical matter, pass the negligence issue largely to the jury through instructions which were not sufficiently precise, he would be forced to meet the problem personally and directly in the other instances.'

When is an indictment or information which charges an offense of which negligence is an element sufficient as a matter of law? What, from the standpoint of the admissibility of endence, is the nature and quality of acts tending to show negligence? What crrcumstances will justify a directed verdict for the defendant? What considerations should guide the judge in commenting on the evidence in Jurisdictions which allow him to do so? What must be shown before the defendant may demand a new trial on the ground that the evidence does not support the verdict? The answer to such questions requires a precise knowledge of what constitutes crimmal negligence. 


\section{SECTION 5. A DEFINITION OF CRIMINAL NEGLIGENCE}

\section{A. Problems Encountered in Formulating a Definition}

It would be futile for the law to attempt to deal in advance by specific detailed rule with each possible instance of negligent conduct. 98 This is because the number of situations where negligence could be an issue is incalculable.

The objective crrcumstances alone present limitless poss1bilities for negligent conduct. The number of dangerous $2 n$ strumentalities, such as automobiles, guns, and poisons, is large. An enumeration of all possible dangerous situations-slippery streets, erowded buildings, and overloaded boats-is beyond the province of the law.

The subjective circumstances offer equal possibilities. The qualities of personality are themselves various, their shadings countless. There is a wide range of mental phenomena, like memory, observation, skill and self-control. Physical qualities are equally multiple. Varıations of bodily characteristics, normal and abnormal, such as age, strength, blindness, and deafness, are endless in number.

Possible combinations of all these circumstances, objective and subjective, are literally infinite. One has only to unleash his imagination for a moment to see a host of old men with rheumatism trying to cross crowded thoroughfares, drunken drivers speeding defective automobiles through throngs of $\mathrm{m}$ different children, inexperienced youngsters recklessly burning leaves on lots located in populous communities, and so on $a d$ infinitum.

Faced with such infinity, cognuzant of the utter umpossibility of formulating specific rules for mdividual situations, the

${ }^{25}$ The law does measure conduct by definife standards in a relatively small number of situations. "These instances are largely confined to police regulations as the 'Stop, Look and Listen' rule, speed limits, sale of pousons, and the like. In these cases precision of conduct is highly desirable. But even here the possible situations are so many that the integrity of those hard and fast rules is not infrequently violated. See Hinton v. Southern R. Co., 172 N.C. 587, 90 S.E. 786 (1916), Standard Oil Co. of New Jersey v. Roberts, 130 Va. 532, 107 S.E. 838 (1921)." Green, op cit. supra note 97, at 1029 . 
law, on the civil side, has adopted a formula for negligence. ${ }^{98}$ Like all such machmery, the formula is abstractly stated, so that it does not fit exactly to the facts of particular cases. However, it permits the problems of individual cases to be "worked down" to a graspable position by judges and juries. Similar machmery us common in the sciences, and it is practically necessary for solving detailed, intricate problems in any field.

The formula, variously worded in the texts and cases, is phrased substantially as follows in the Restatement of Torts :100

(1) Negligence is any conduct, except conduct recklessly or wantonly disregardful of an interest of others, which falls below the standard established by law for the protection of others agaunst unreasonable risk of harm. ${ }^{101}$ The standard of conduct chosen is that of a reasonable man under like crrcumstances.

(2) Negligent conduct may be either:

(a) an act which the actor as a reasonable man should realize as involving an unreasonable risk of causing an invasion of an interest of another, or

(b) a failure to do an act which is necessary for the protection or assistance of another and which the actor is under a duty to do.

This formula has been of immense practical value in the determination of negligence cases on the civil side of the docket. But judges and juries have had no such standard to follow on the crimmal side.102 No Chref Justice Tindall ${ }^{103}$ or Baron Alderson ${ }^{104}$ has pointed the way here.

an "But since it is impossible to anticipate the innumerable combinations of curcumstances which may arise, it is impossible for the law to formulate in advance definite standards by which the propriety of conduct under every concelvable set of circumstances may be judged. It can at best announce broad general principles, which give the materials and general directions for the construction of the standard to be applied in each particular case." Bohlen, Mixed Questions of Law and Fact (1923) 72 U. of Pa. L. Rev. 111, 113.

${ }^{100}$ Restatement, Torts (1934) secs. 282-284.

${ }^{202}$ Note that the definition excludes reckless or wanton conduct. See Restatement, Torts (1934) sec. 282, comment d, and Special Note on page 740 . The definition in the Restatement does not differentiate between "reckless" and "wanton" conduct, excepting only "conduct recklessly disregardful," but. the words are not synonymous and the difference between them has been used later in this paper to distinguish the degrees of negligence required for manslaughter and murder.

102 'Every judge has endeavored to find out a crisp, clear definition that will assist judges like myself in instructing jurors, and every judge has, I think, failed. And I think the most conspicuous failure of all is that given in the close of the book from which $\mathrm{Mr}$. 'Johnston (counsel' for the prisoner) has quoted-Lord Halsbury's 
The lack of a formula for crimmal negligence has been due, in part, to the passive submission of judges to the difficulties of the situation. Too readily have they admitted therr mability to define or describe it. ${ }^{105}$

This attitude has been partially responsible for the failure to determine just what are the fundamental problems involved and to find some solution for them. For example, although frequent references to the "ordinary prudent man" will be found in crimunal cases, ${ }^{106}$ judges have not frankly faced the issue whether criminal negligence is objective or subjective. Negligence on the civil side is objectrve as far as possible.107 The ordinary prudent man is an objective abstraction, has he been consciously used as such in the criminal cases?

Presumably the courts have answered this question in themr enunciation of the now familiar rule that esvil and criminal negligence are the same in kind, 108 they differ only in degree. ${ }^{109}$

Laws of England, Volume 9, page 582." Rex v. Murphy, 49 Ir. L.T. 15,16 (1915).

${ }^{103}$ See his opimion in Vaughan v. Menlove, 3 Bingham's New Cases, 468 (1837).

10 The definition of negligence which is most frequently quoted is taken in large part from his opinion in Blythe v. Birmingham, 11 Exchequer 781 (1856).

${ }^{100}$ Turner, supra, note 21 , at 40.

${ }^{100}$ Fitzgerald v. State, 112 Ala. 34, 20 So. 966 (1896); People v. Marcon1, $\mathrm{Cal}$, $5 \mathrm{P}$ (2d) 974 (1931); Bell v. People, $125 \mathrm{II} .584,17 \mathrm{~N} . \mathrm{E} .744$ (1888), State v. Hardie, 47 Fowa 647 (1878), State v. Warmer, 157 Iowa 124, 137 N.W 466 (1912), State v. Nevils, 330 Mo. 831, 51 S.W (2d) 47 (1932), Com. v. Breth, 44 Pa. Co. Ct. 56 (1915). See Note (1937) 6 Fordham L. Rev. 311, fn. 11.

${ }^{107}$ See pp. 32-33, infra.

108 "The social purpose underlyng the requurement of compensation to the person harmed is not identical with that which forms the basis of punishment. Concelvably, therefore, the standard adopted in the criminal law of negligence might be entirely different from that used in clvil cases. This is not exactly the answer since the 'measuring stick' here, as well as there, is the conduct of a reasonable man under like crrcumstances. But whereas the civil law requires conformity to this standard, a very substantial deviation is essential to crimmal guilt." Perkins, Rationale of Mens Rea (1939) 52 Harv. L. Rev. 905, 914-915. And see Miller on Crumunal Law (1934) 66 .

"Between crmmul negligence, however, and actionable negligence, there is no principle of discrimination, but a question of degree only." Nail v. State, 33 Okla. Cr. 111, 242 Pac. 270, 272 (1925), citing Bevan on Negligence.

100 'It is 'uniformly held,' sard the Florida court, that the kind of negligence required to impose criminal guilt, 'must be of a higher 
However; it may be doubted whether the judges are fully aware of the import of their words as used in thes rule. By stating that the two are the same in kond, they are, in effect, admitting that the crimmal standard is also objective, and that culpability, as the term is popularly used, has no part in determining crimmality in negligence cases.

Whether the courts understand its implications or not, the rule that crvil and crimunal negligence differ only in degree raises the second major problem which has been inadequately treated in the decisions. How are judges and juries to know when this "higher degree" which would make the defendant criminally liable is reached?

While the distmetion between the negligence which is sufficient ground for a civil action and the "higher degree" which is necessary in crimmal cases is sharply insisted upon, a test by which the judge or jury might determine just when the higher degree has been reached has by no means been made clear.

In attempting to describe this higher degree of negligence, certain "vivid adjectives" 110 are commonly used in connection with the word negligence. For example, "gross,"111 "criminal,"112 "culpable,"113 "clear,"114 "complete,"115 "wil-

degree than that requured to establish simple negligence upon a mere civil issue." Perkins, supra, note 108, at 914-915.

"While the kind of negligence required to impose criminal liability has been described in different terms in different jurisdictions, it is uniformly held that it must be of a higher degree than that required to establish simple negligence upon a mere civil Issue." Cannon v. State, 91 Fla. 214, 107 So. 360, 363 (1926).

"Negligence is the failure to exercuse ordinary care. Gross negligence may consist in the failure to exercise any or very slight care So we may truly say that negligence differs only in degree." Johnson v. State, 66 Ohıo St. 69, 63 N.E. 607, 609 (1902) And see State v. Cope, 204 N.C. 28, 167 S.E. 456 (1933), Copeland v. State, 154 Tenn. 7, 285 S.W 565 (1926), 29 C.J. 1154 (citing cases)

${ }^{110}$ Turner, Mens Rea and Motorists (1935) 5 Camb. L. J. 61, 64.

"Held v. Com., $183 \mathrm{Ky}$ 209, 215, 208 S.W 772, 775 (1919), Jones v. Com., $213 \mathrm{Ky}$ 356, 359, 281 S.W 164, 166 (1926), R. v. Markuss, 4 F \& F. 356, 359 (1864), Rex v. Allen, 7 C. \& P 153, 164 (1835)

12 Carbo v. State, 4 Ga. App. 583, 62 S.E. 140, 140 (1908); Schultz v. State, 89 Neb. $34, \stackrel{1}{\longrightarrow}, 130$ N.W 972, 977 (1911); State v. Goertz, 83 Conn. 437,, 76 Atl. 1000, 1002 (1910); State v. Irvine, 126 La. 434, 52 So. 567, 569 (1910), R. v. Elliott, 16 Cox, C. C. $710,714^{\circ}$ (1889).

${ }^{113}$ State v. Lester, 127 Minn. 282, —, 149 N.W 297, 298 (1914);

Nail v. State, 33 Okla. Cr. 100, 242 Pac. 270,272 (1926); R. v.

Doherty, 16 Cox, C. C. 306,309 (1887) 
ful,"116 and "wanton,"117 are often employed. And the "vituperative epithet" of Baron Rolfe $e^{118}$ is. found literally in the use of "wicked" as an and in determining the degree of negligence necessary for crmmal liability These help little. They are not used in their dictionary sense, often far from it, but as "vague adjectives,"119 straws flung to jurors drowning in a sea of uncertamty by judges floundering in like waters. Formless, without substance, they offer small relief.

Words grown to phrases are more helpful but still not satisfyng. In People v. Goertz, ${ }^{120}$ the court held that the defendant must be guilty of "recklessness of conduct, gross or wanton carelessness," Importing a "thoughtless disregard for consequences." People $\mathrm{v}$ Adams 121 deseribes the standard as "negligence that borders on recklessness," "positive disregard of the rules of diligence" and "reckless heedlessness of consequences." In State v. Dorsey, 122 the phrase, "wanton or reckless disregard of the rights and safety of others" is used. Dozens of similar phrases may be found in the decisions. In England, it is necessary that the negligence of the accused go "beyond a mere matter of compensation between subjects", it must show "such disregard for the life and safety of others as to amount to a crime against the State and conduct deserving punishment." 123

ut R. v. Macleod, 12 Cox, C. C. 534, 538 (1874)

${ }^{215}$ R. V. Noakes, 4 F \& F 920, 921 (1866).

${ }^{116}$ People v. Swartz, 298 Ill. 218, —, 131 N.E. 806, 808 (1921).

${ }^{117}$ People v. Adams, 289 กI. 339, —, 124 N.E. 575, 577 (1919), People v. Herkless, 361 Ill. 32, —, 196 N.E. 829, 833 (1925); Jones v. Com., $213 \mathrm{Ky} .356,360,281$ S.W 164, 167 (1926)

us "I sard I could see no difference between negligence and gross negligence-that it was the same thing, with the addition of a vituperative epithet." Rolfe, B., in Wilson v. Brett, 11 M. \& W 113, 115-116 (1843) (Italics ours).

110 Turner, supra, note 21 , at 38 .

2003 Conn. $437,-, 76$ Atl. 1000, 1002 (1910)

221289 III. 339 , —, 124 N.E. 575, 577 (1919).

120218 Ind. 167, —, 20 N.E. 777, 778 (1889).

120 Rex v. Bateman, $19 \mathrm{Cr}$. App. Rep. 8, 11-12 (1925), Andrews v. Director of Public Prosecutions (1937) A.C. 576, 582-583.

Recent Canadian cases have followed the standard prescribed in Rex v. Bateman. The language in individual cases is interesting. "I think the great weight of authority goes to show that there will be no cruminal liability unless there is gross negligence, or wanton misconduct. To constitute crime, there must be a certain moral quality carried into the act before it becomes culpable. In each case it is a question of fact; and it is the duty of the Court to 
There is little in either the English or American decisions to offer and in describing the degree of negligence necessary for crimmal liability other than these, or similar, vivid adjectives and vague phrases. Small wonder that, as Mr. Turner points out, "in some cases the attempt to elucidate the principles to be applied is abandoned and the question of what is to be done with the person in the dock is handed over to the jury, who are left, without any proper gurdance, to come to a decision under any chance influence that may happen to be operating at the moment in their minds-even such as may be aroused by the personal appearance of the prisoner, his calling, demeanor, or social position."124

ascertain if there was such wanton and reckless negligence as in the eye of the law merits punishment. This may be found where a general intention to disregard the law is shown or a reckless disregard of the rights of others." Rex. v. Greisman, 4 D.L.R. 738, 743,46 Can. C.C. 172 (1926) Note the similarity between the language here and the phrase "conduct deserving punishment" in the Bateman case.

"Whether the negligence in any case is of such a character as to justify conviction upon a criminal charge must depend upon the particular facts of the case itself. In order to found a criminal charge, there must be present such a degree of want $o^{*}$ care as to involve a moral element; such a wanton or reckless indifference as to the lives and safety of others, as would lead one to say "The State should punish that man." "Rex v. Baker, 1 D.L.R. 785, $792-793,51$ Can. C.C. 71 (1929)

"In reference to manslaughter by negligence the legal and popular meanings of the word are nearly identical as far as the popular meaning goes; but in order that negligence may be culpable it must be of such a nature that the jury think that a person who caused death by it ought to be punished; in other words, it must be of such a nature that the person guilty of it might and ought to have known that neglect in that particular would, or probably might, cause appreciable positive danger to life or health, and whether this was so or not must depend upon the curcumstances of each particular case." 2 Stephen, History of the Crimmal Law of England (1883) 123. The opunion in Rex $v$ Bateman does not mention this source but the similarity in language and thought is striking.

121 Turner, supra note 21 , at 40 . The same 1 dea, expressed with less apprehension, is found in the following extract from an opinion by Dodd, J..

"Negligence is entirely a question of degree. Some judges say 'gross negligence,' other judges put it in Latin and say 'crassa negligentia.' That does not convey to my mind any kind of meaning. There is a negligence that can be met and amply met by damages, and there is a negligence that cannot be amply met by damages, because it goes aganst the public. Who is to draw the line? Can any judge supply a scientific definition? There is none such that I can find in any reported case. Where the breach of duty that ends in damages and where the other that ought to be punished as an offense against the public begins, is for the jury in the box. Is this an offense for which the accused ought to be criminally pun- 
It becomes apparent that the cruminal cases do not offer a solution to the problem of determining what is crmmal negligence. One must turn elsewhere, if he is to obtain substantial assistance:

\section{B. The Proposed Definition}

The logical place to turn for ard is to the eivil cases where a satisfactory formula for negligence is already in operation. It is believed that this definition might serve as a base for a definition of negligence in the criminal field. With this premise in mind, the following formula for criminal negligence is suggested : 125

(1) Criminal negligence is conduct creating such an unreasonable risk of harm to life, safety, property or other interest for the unintentional invasion of which the law prescribes punishment, as to be recklessiy disregardful of such interest..$^{203}$ The standard of conduct to be applied is that of a reasonable man under like circumstances. ${ }^{297}$

(2) Criminally negligent conduct may be either:

(a) An act which the actor as a reasonable man should realize as involving under the curcumstances a reckless disregard of an interest of others, or

(b) A failure to perform a legal duty which the actor as a reasonable man should realize amounts to a reckless disregard for human life and safety under the crrcumstances.

ished? Is it an offense for which he ought to go to gaol? Is this an offense for which his employer ought to pay damages, and might that end it? 'Can you assist us in that, judge?' No! It is the glory of the country that it is twelve men who have to decide upon the criminality of their fellows, and not a judge." Rex. v. Murphy, 49 Ir. L.T. 16 (1914).

${ }^{203}$ See Restatement, Torts (1934) secs. 282-284 and comments and Perkins, supra note 108, at 913-915.

${ }_{120}$ Wanton conduct is not included in the phrase "recklessly disregardful." See fn. 101, supra.

It should be pointed out that there is no particular efficacy in the exact words and phrases used in the suggested formula. The civil formula is variously stated in the cases and texts and the wording in the Restatement is a new and more or less novel one. The same fundamental idea can be expressed in a number of ways.

For example, The Restatement points out that the phrase, "conduct involving unreasonable risk" is substantially synonymous with the phrases, "unduly dangerous conduct" and "unreasonably dangerous conduct." Restatement, Torts, op. cit. supra note 100, at sec. 282, comment b.

Consequently, a number of alternate definitions of crimmal negligence, all worded somewhat differently but substantially alike, may be formulated. For example:

Crimmal negligence is such unreasonably dangerous con-

duct that the actor as an ordinary prudent man should realize it involves, considering the crrcumstances, a reckless disregard for the legally protected interests of others. 
This formula ties up criminal and civil negligence definitely, using so far as possible, the language in the Restatement of Torts, as the common measure of expression. If eivil and crimmal negligence are the same in knd, there are distinct advantages in such common statement. It facilitates therr development along parallel lines, so far as that is expedient, and makes studies and judicial opmions in either field of substantial value in the other.

The formula, like all others, may be criticised. It is diffcult to frame the principles of negligence in a few sentences. "The abstractions of the law are hard to handle."12s Nevertheless, the formula brings to the surface the most important problems in crimunal negligence. The first of these is presented by the enunciation that negligence is "conduct," the second by the attempt to describe the "higher degree" of negligence necessary for criminal liability by stating that conduct to be cruminal must create such an unreasonable rusk of harm as to be "recklessly disregardful" of an interest of others. Of course, the concepts, "conduct" and "recklessly disregardful" must be broken down in order that they may be intelligently applied to individual cases. The abstract statement of a formula us only the first step in a long process.

The standard of conduct chosen in the crmmal formula, as in the civil, is that of "a reasonable man under like circumstances."129 The phrase, "reasonable man," is synonymous

${ }^{223}$ Green, op. cit. supra note 97, at 1031, n. 5. "Concepts whether vague or precise are imperiled by the very words to which they are intrusted. Any adequate science of law awaits a science of statement. The definitions of scholars are sieves, the opinions of judges little more than a succession of murages, even the precedents by which the course of judicial decision is determmed are equally expansible and collapsible. But analysis and classification are indispensable. Though they retard the very progress they would promote, they are nevertheless the machunery through which the law and lawyers function. They are the most reliable ands to passing Judgment, but they cannot take the place of Judgment." Ibrd.

120 "It is contended that the question ought to have been whether the defendant had acted honestly and bona fide to the best of his own judgment. That, however, would leave so vague a line as to afford no rule at all, the degree of judgment belonging to each individual being infinitely various.

" Instead, therefore, of saying that the liability for negligence should be coextensive with the judgment of each individual, which would be as variable as the length of the foot of each individual, we ought rather to adhere to the rule, which requires in 
with the well known "ordinary prudent man,"130 commonly used in the cases.

The selection of a standard so strict as to condemn conduct not considered blameworthy according to the general opinion of the community would be not only harsh and unpopular, ${ }^{131}$ it would be illogical. It is true that some people are more cautious than the "average." Such individuals hesitate to take risks commonly accepted without question by the ordinary person. It might be argued that they are more desirable citizens because of their additional prudence, but this may well be doubted. A certain amount of risk is utilitarian.

On the other hand, there are mdinduals, less cautious than the average person, who go through life takung risks, often with no feeling of social culpability, that "a reasonable man" would not think of uncurring. Frequently such persons are dangercreating without relation to the matter of utility, takng undue risks for no good reason. Their "governors" (to take an analogy from the realm of mechanies) function at a higher

all cases a regard to caution such as a man of ordinary prudence would observe." Vaughan v. Menlove, 3 .Bing. New Cas. 468 (1837).

"Negligence is the omission to do something which a reasonable man, guded upon those considerations which ordinarily regulate the conduct of human affaurs, would do, or doung something which a prudent and reasonable man would not do." Blyth v. Birmingham Waterworks Co., 11 Exch. 781, 784 (1856).

See the following criminal cases: Fitzgerald v. State, 112 Ala. 34, 20 So. 966 (1896); People v. Marcon, 1 Cal. _ 5 P (2d) 974 (1931); Belk v. People, 125 IIl. 584, 17 N.E. 744 (1888); State v. Hardie, 47 Iowa 647 (1878); State v. Warner, 157 Iowa 124, 137 N.W 466 (1912) - State v. Nevils, 330 Mo. 831, 51'S.W (2d) 47 (1932); Com. v. Breth, $44 \mathrm{~Pa}$. Co. Ct. 56 (1915).

120 "Pollock defines the standard as 'the foresight and caution of a prudent man-the average prudent man.' Pollock, Torts (12th ed. 1923) 444; Harper, Torts (1933) 159 as the 'ordinary reasonably prudent man' which he says is 'a pure fiction'; in Lundy $v$ Tel. Co., 90 S.C. 25,72 S.E. 558, 564 (1911), it is 'a person of ordinary intelligence and prudence'; in Arkansas and La. R.R. v. Sanders, 81 Ark. 604, 99 S.W 1109 (1907), a 'reasonably prudent man'; in Keith v. Worcester and Blackstone St. Ry., 196 Mass. 478,82 N.E. 680 (1907), a man 'reasonably prudent and careful'; in Davis v. Concord and Montreal R.R., 68 N.H. 247, 44 Atl. 388 (1895), a 'person of average prudence." "Note (1939) 28 Ky L. J. 237-239.

isi "A law which punished conduct which would not be blameworthy in the average member of the community would be too severe for that community to bear." Holmes, The Common Law (1881) 50 .

"The first requirement of a sound body of law is that it should correspond with the actual feelings and demands of the community, whether right or wrong." Id, at 41. And see Wechsler and Michael, supra note 76 , at 749 , especially fn. 172. 
"speed" (risk) than those of ordinary persons. Under circumstances where the average operator would drive an automobile at 50 miles an hour they habitually drive at 60 or higher. The taking of this added and unusual risk comes to them naturally,they do not intend to be reckless in their conduct.

The norm of conduct has been placed somewhere between the two extremes. The "average" person in the community has been selected.132 Such a "person", 1s, of course, a pure fiction. He does not exist. Nevertheless, in practice, the formula works out farrly well. If it is applied by a jury, "a slice of the community," they are apt to draw a "composite picture" of a reasonable man in their deliberations which represents with reasonable exactitude the standard of the community If the formula is employed by the court in passing upon a demurrer or other pleading, there is a lilkelihood that the judge, who us also selected from the community, will be able to envisage an ordinary prudent man who is representative of the standard to be applied.

\section{The ObJectivity of Negligence}

It can be seen that the definition of crmmal negligence whuch has been suggested makes no provision for the state of mind of the actor. To the extent that negligence is regarded as unreasonably dangerous conduct, and conduct is evaluated with reference to an abstraction (a reasonable man under like circumstances), an objective standard is applied.133 Although negligence may and generally does result from a careless state

132" The reasonableness of the danger and the care and caution necessary to avold it are to be determined, not by reference to any individual or group of individuals, but by reference to the assumed 'average' person-the 'ordinary reasonably prudent man.' This, of course, is a pure fiction. Any judgment of what is 'reasonable' must be some person's judgment. What is sought is a judgment which, as far as possible, represents the general level of moral judgment of the community. Not the judgment of the most cautious nor the most reckless, but a judgment which, to use another fiction, will faurly represent the social or community notion of what is right, sensible and proper." Harper, Law of Torts (1933) 158-159.

${ }^{123}$ See State v. Pickus, 63 S.D. 257, 257 N.W 284, 293 (1934), where the court, in definung the standard, sard:

"Negligence, of course, is a failure to comply with an objective standard-the failure to exercise such degree of care as would be exercised under the circumstances by a reasonably prudent man." 
of mmd, 134 the mental element is not material. 135 Courts approach the problem objectively by mquiring whether the actor's behavior was such as to meet the standard which society has preseribed. ${ }^{136}$

134 The same result is reached in most cases whether the conduct theory or the mental theory is followed. "I have found few cases in which the conduct view has clearly led to a result that could not have been reached on the basis of the mental view." Edgerton, Negligence, Inadvertence and Indifference: The Relation of Mental States to Negligence (1926) 39 Harv. L. Rev. 849, 854.

235 "Jurisprudence is not psychology, and law disregards many psychological distinctions not because lawyers are ignorant of their existence, but because it is impracticable or useless to regard them. Even if the terms were used by lawyers in a peculiar.sense, there would be no need for apology; but the legal sense is the natural one. Negligence is the contrary of diligence, and no one describes diligence as a state of mind. The question for judges and juries is not what a man was thinking or not thinking about, expecting or not expecting, but whether his behavior was or was not such as we demand of a prudent man under the given circumstances." Pollock, op cit. supra note 130, at 443 . The entire discussion, pp. 442-447, is illuminating.

"In either case one never gets to the mental state of the actor. One gets only to objective factors, which seem to indicate the existence of a mental state. The entire method of procedure is objective. The subjective aspects may be talked about, but they are never actually reached." Levitt, Extent and Function of the Doctrine of Mens Rea (1923) 17 il. L. Rev. 578, 589.

The most striking indication that no blameworthy state of mund is necessary to establish crimmal liability is found in such cases as Com. v. Breth, 44 Pa. C.C. 56 (1916) In that case the father of a five-months-old child, knowing that the child was dangerously ill, refused to provide medical attention for it, under the belief that prayer was all that was necessary. In pursuance of this belief, he and others resorted to prayer for the child's recovery, but it died. The father was convicted of involuntary manslaughter.

In such cases the courts apply the familiar principle that religious conviction is not an excuse for a failure to meet the objective standards enforced by the community. Where such individuals are motivated conscientiously, it is difficult to work out any subjective blameworthiness, - if a Christian nation actually believes what it professes. See Lee, Lrability of Parent at Common Law on Charge of Manslaughter for Negligently Omitting to Furnush Medical Attendance to Child Because of Religıous Disbelief in the Efficacy of Medicine (1902) 44; note on Com. v. Breth (1916) $65 \mathrm{U}$. of Pa. L. Rev. 88; Sayre, Cases on Criminal Law (1927) 176, fn. 1 .

${ }^{283}$ Edgerton, supra note 134, at 849; Restatement, Torts, op. cit. supra note 100 , at sec. 282; Harper, op. cit. supra note 132 , at sec. 68; Holmes, op. cit. supra note 131, at 49-50; May's Criminal Law (4th ed. 1938) secs. 24-28.

It was to this that Cardozo had reference when he stated:

"Negligence as a term of legal art is, strictly speaking, a misnomer, for negligence connotes to the ordinary man the notion of lack of care, and yet one can be negligent in the view of the law though one has taken what one has supposed to be extraordinary 
The accentuation upon the objective in negligence is occasioned by the fact that the law is primarily interested in maintaming the general security, not in awarding punushment for blameworthy mental attitudes. ${ }^{137}$

The new that crimmal negligence, like civil, is unreasonably dangerous conduct rather than an indifferent state of mind, is, of course, at variance with the popular conception that some sort of mens rea is a necessary ingredient of every crme at

care, and not negligent though one has taken no care at all. Moreover, one can deliberately choose to be indifferent to the greatest peril, and yet avold the charge of negligence for all one's scorn of prudence.

"Two factors, both social, contribute to the paradox. The first is the conception of the 'reasonable man,' the man who conforms in conduct to the common standards of society If the individual falls short of the standards of the group, he does so at his peril. He must then answer for his negligence though his attention never flagged. Enough that a reasonable man would have appreciated the peril which because of stupldity or ignorance may have been hidden to the actor $\mathrm{By}$ and large with whatever allowance may be made for deviation or exception, the test of liability is external and objective." Cardozo, The Paradoxes of Legal Science (1928) 72-74.

Precisely the same idea is expressed by Edgerton as follows:

"The proposition that negligence is conduct means that there is negligence if there are unreasonably dangerous motions, and not otherwise; consequently, that no particular mental shortcoming proves negligence or is necessary to negligence, and no particular mental attainment precludes negligence. Non-negligent conduct, and consequent freedom from liability, may coexust with a mental state that is dangerous, as involving inadvertence, lack of normal anxiety to avord harm, or any other unsafe mental fact; negligent conduct, and consequent liability, may coexist with normal and proper advertence and anxiety." Edgerton, supra, at $\mathbf{8 5 4}$.

137 " the aim of the law is not to punish sins, but is to prevent certain external results " Holmes, J., in Com. v. Kennedy, 170 Mass. 18, 48 N.E. 770 (1897).

"Our modern objective tends more and more in the direction, not of awarding adequate punishment for moral wrong-doing, but of protecting social and public interests. To the extent that this objective prevails, the mental element requsite for crumunality, if not altogether dispensed with, is coming to mean, not so much a mind bent on evil-doing, as an intent to do that which unduly endangers socral and public interests." Sayre, supra note 4, at 1017.

"Liability (in negligence) is now apportioned to the degree of risk to life and limb created, rather than to the moral delinquencies of the defendant. The crimes of murder, manslaughter, and assault and battery are being used in an attempt to control the reckless use of dangerous instrumentalities which modern inventions have intrusted to unskilled hands, in addition to their older function of punishing intended injuries." Hall, The Substantive Law of Crimes (1937) 50 Harv. L. Rev. 616, 642. 
common law. ${ }^{138}$ In rendering homage to the supposed necessity of mens rea, ${ }^{139}$ however, it has frequently been necessary for judges and writers to resort to a number of questronable expedients, commonly classified under the somewhat anomalous heading, "constructive intent."

In the case of negligence, some courts have sand that the law infers intention from reckless conduct; ${ }^{\mathbf{1 4 0}}$ others, that a person is presumed to intend all the natural and probable consequences of his acts. ${ }^{141}$ One device is to say that negligence implies intent. ${ }^{142}$ A hardly less satisfactory expression is that negligence supplies the necessary intent. ${ }^{143}$

The fundamental objection to all these explanations is that they cloud the issue. If "intent" as used in them has any meaning, it is a conveniently esoteric one. Resort to such fictions may have been justified when an evil mond was considered a requisite element of crime, but, today, with a widen-

130 This doctrine dates from the latter part of the twelfth century. It is then for the first time that a real emphasis upon the mental element in crime is found. As Sayre points out, this was Iargely due to two strong forces. The resuscitated Roman law with its emphasis upon dolus and culpa stressed the psychical element in crmmal liability Bracton, the first great English law writer, was to borrow liberally from it in the next century. The second force was the canon law with its persistent and relentless accent upon moral guilt. See Sayre, supra note 4, at 982; 2 Pollock \& Maitland, op cit. supra note 1 , at 477 .

It was due directly to the influence of the canon law that the phrase "mens rea" was first used. It is found in the middle of Leges Henricl. This book contains many survivals of the earlier period of absolute liability. And yet, in the muddle of such rules holding a man responsible for his acts, regardless of intent, in a discussion of perjury, is found, "reum non facit nisi mens rea." A number of writers have followed Maitland in showing that the phrase goes back to St. Augustine. 2 Pollock \& Maitland, op cit supra note 1 , at 476 , fn. 5. See Levitt, The Orngnn of the Doctrine of Mens Rea (1922) 17 Iil. L. Rev 117. Once in a "book of the law" the phrase stuck tenaciously and attained a position of dominating influence in the crimunal law.

120 There are recognized exceptions to the requirement of mens rea. See Sayre, Public Welfare Offenses (1933) 33 Col. L. Rev. 55; May, op cit. supra note 136, at 3, fn. 18; 1d. at sec. 38 .

160 Pool v. State, 87 Ga. 526, 13 S.E. 556 (1891) See Clark and Marshall on Crimes (3rd ed. 1927) sec. 51.

212 State V Barnard, 88 N.C. 661 (1883).

2: Hampton v. State, 45 Ala. 82 (1871)

${ }_{14}$ Com. v. Hawkuns, 157 Mass. 551, 32 N.E. 862 (1893), Fitzgerald v. State, 112 Ala. 34, 20 So. 966 (1895), State v. Barnard, 88 N.C. 661 (1883).

"Negligence is one way of supplying a sufficient crimmal intent to make a criminal act punishable." Note (1899) 12 Harv. L. Rev. 428. See Keedy, Ignorance and Mistake in the Criminal Law (1908) 22 Harv. L. Rev. 75, 83. 
Ing use of non-mens-rea crimes, 144 this requrement is :not as Important as it was. 145 The modern objective tends more and more toward the "societal harm" of the act and less and less toward the moral wrongdoing of the defendant in the determnation of substantive guilt. ${ }^{146}$ Consequently, such misnomers as "constructive intent" are falling into disfavor.

It is believed that, excluding the negligent murder, a blameworthy mental state is not essential to cruminal liability in neg-

${ }^{14}$ Hall, supra note 137 , at 652; Sayre, supra note 4, at 1017 .

The general trend toward the objective is indicated, also, by the increase un statutes creating liability on the doing of a prohibited act, regardless of intent. For example: "The doing of the mhibited act constitutes the crime and the moral turpitude or purity of the motive by which it was prompted and knowledge or ignorance of its criminal character are immaterial circumstances on the question of guilt." Com. v. Mixer, 207 Mass. 141, 93 N.F. 249 (1910).

14 "These two standards, the objective and the subjective, have been our crimunal law since the thurteenth century. They have existed, side by side, at times without clashing, at times in close conflict. The objective view, however, has gradually been gaining the ascendancy. At the present time I think the subjective aspect is practically elimmated as an element of any specific crime, and maintains whatever hold it has because of the idea that a crime is an act for which the offender must be punshed. This idea is tied up with the notion that punishment should not be inflicted upon one who did not act as a free moral agent and who did not possess the will to evil which is the central idea of the classical theory of punishment. Modern crimunology, however, while not ignoring the will to evil, is not interested in it as a metaphysical speculation or as a test for determining a future state of bliss or misery. It looks at the evil will as a psychological and sociological phenomenon. Naturally, then, where the classicist thought of punishment the modernist thinks of rehabilitation and reconstruction. Our criminal law, while concerned, practically unwittingly, with freeing itself from domination by Augustinian metaphysics, has reached a point where, to my mind, it is ready and able to re-adopt the objective standard for determining whether a crime has been committed or not, and, at the same time, accept the and of the modern crimmologist in utilizing the subjective standard when punishments are to be imposed." Levitt, supra note 135 , at 578 .

110 "Indeed, the strong current of modern decisions toward applying in the cruminal law an objective standard, to which all must measure up at their peril, in place of the older subjective standard, under which defendants are punishable only for failing to measure up to their own capacities, is only another manifestation of the same trend of the crimmal law. Certain it is that in modern times we have moved far from 'the old fourteenth century conception of mens rea as a mind bent on moral wrongdoing." Sayre, supra note 4 , at 1019 .

"If intent means anythung in these cases it is. merely a twosyllabled method of expressing conveniently a set of operative facts. Defendant, then, in case two is held guilty on the unexpressed assumption that such conduct is more dangerous to society than the conduct of the defendant in case. three, and that, conse- 
ligence. ${ }^{147}$ The real criterion is whether the aecused has met the standard of conduct which the law has prescribed. ${ }^{148}$ To say that the actor is presumed to have intended the consequences of his negligent conduct, or to infer, ${ }^{149}$ as a matter of law a blameworthy mental state from the erreumstances, is to disguise the truth. What the law really does is to disregard the mental state, ${ }^{150}$ except. in the case of the negligent mur-

quently, more benefit is to be derived-by punishing the former defendant than the latter." Tulin, The Role of Penalties in Criminal Law (1927) 37 Yale L. J. 1046, 1055.

${ }^{117}$ Pollock, $M r$ Justice Holmes (1931) 44 Harv. L. Rev. 693, 694. See Pound, An Introduction to the Philosophy of Law (1922) 177179. Mr. Pound is speaking here of crvil negligence but it is submitted that the discussion is equally applicable to crumunal negligence.

14s "But what the law is really regarding is not his culpable exercise of his will but the danger to the general security if he and his fellows act affirmatively without coming up to the standard imposed to maintain that security If he acts he must measure up to that standard at his peril of answering for injurious consequences. Wherever a case of negligence calls for sharp application of the objective standard, fault is as much a dogmatic fiction as is representation in the liability of the master for the torts of his servant. In each case the exigencies of the will theory lead us to cover up a liability urrespective of fault, imposed to maintain the general security, by a conclusive imputation of fault to one who may be normally blameless. Pound, op cit. supra note 147, at 178-179.

"It is familiar law that an act causing death may be murder, manslaughter, or misadventure, according to the degree of danger attending it. If the danger is very great it is murder The very meaning of the fiction of implied malice in such cases at common law was, that a man might have to answer with his life for consequences which he neither intended nor foresaw. To say that he was presumed to have intended them, is merely to adopt another fiction, and to disguise the truth. The truth was, that his failure or unability to predict them was immaterial, if, under the circumstances known to him, the court or jury, as the case might be, thought them obvious." Holmes, J., in Com. v. Pierce, 138 Mass. 165,178 (1884).

160 This is the most logical basis for a support of the subjective theory of crimunal negligence. While plausible in most cases, it breaks down in a number of situations. See, for example, the discussion of Com. v. Breth, supra note 135.

${ }^{150}$ As far as blameworthiness is concerned, is meant. There are some physical and mental attributes which the law permits the jury to consider. Green, op cit. supra note 97 . "Reviewing the whole matter briefly, it would appear that there is no standardized man; that there is only in part an objective test; that there is no such thing as reasonable or unreasonable conduct except as viewed with reference to certain qualities of the actor-his physical attributes, probably, - if superior, his intellectual powers, his knowledge and the knowledge he would have acquired had he exercised stand- 
der, ${ }^{151}$ and look at the amount of danger in the conduct of the accused when determining his guilt or innocence. Such a theory of negligence is founded on blameworthmess no less than a subjective one. The difference lies in the fact that the tests of blameworthiness are external and "independent of the degree of evil in the particular person's motives or intentions."152

(To be Continued)

ard moral and at least average mental qualities at the time of action or at some connected time." Seavey, Negligence-Subjective or Objective (1927) 41 Harv. L. Rev. 1, 27.

This matter is discussed in more detail in this paper, infra.

${ }^{151}$ It is doubtful whether the common law judges carried the law of murder so far along the line of externality. Wechsler and Michael, supra note 76, at 710 . Stephen believed that the accused must have "knowledge" of the danger and not merely of the crrcumstances. 3 Stephen, op. cit. supra note 3 , at 22 . That remams the law in England today Reg. v. Vamplew, 3 F \& F 520 (1862). See Turner, supra note 21, at 37-48. However, Holmes maintained in his book on The Common Law and in a series of cases in which he wrote the opmions that it is immaterial whether the accused knew the danger if he was aware of circumstances that would lead an ordinary prudent man to appreciate that the danger was very great. Holmes, op cit. supra note 131, at 53-57; Com. v. Pierce, 138 Mass. 165, 178 (1884), Com. v Chance, 174 Mass. 245, 252, 54 N.E. 551, 554 (1899), The Germanic, 196 U.S. 589, 596, 41 L. ed. 610,613 (1904), Nash v U.S., 229 U.S. 373, 377, 57 L. ed. 1232, 1235 (1913). See Note (1939) 28 Ky L. J. 53. The writer adopts Stephen's view. See the discussion, infra.

The trend in the United States toward the objective theory in negligence has been quite apparent in the case of assault and battery. Practically all jurisdictions now recognuze the negligent battery This is usually accomplished by a stramed interpretation of "intent." See Com. v. Hawkins, 157 Mass. 551, 32 N.E. 862 (1893), Tift $v$ State, 17 Ga. App. 663, 88 S.E. 41 (1915), State v. Schutte, 87 N.J.L. 15, 93 Atl. 112 (1915). See May, op cit. supra note 136 , at sec. 159 .

Further discussion of the character of negligence in murder and in assault and battery will be found, infra.

It is omitted at this point in order to avoid repetition.

${ }^{162}$ Holmes, op cit. supra note 131 , at 50. 